\title{
Accounting Practices of SMEs: A Case Study of Kumasi Metropolis in Ghana
}

\author{
Gilbert Kwabena Amoako ${ }^{1}$ \\ ${ }^{1}$ Department of Accountancy, Kumasi Polytechnic, Ghana \\ Correspondence: Gilbert Kwabena Amoako, Department of Accountancy, Kumasi Polytechnic, Ghana. E-mail: \\ amoakous1@yahoo.com
}

Received: August 24, 2013

Accepted: November 7, $2013 \quad$ Online Published: November 20, 2013

doi:10.5539/ijbm.v8n24p73

URL: http://dx.doi.org/10.5539/ijbm.v8n24p73

\begin{abstract}
The importance of maintaining proper books of accounts and sound accounting practices has been emphasised in ensuring proper financial management in SMEs. In this study, we investigate the record keeping strategies utilized by SMEs in Kumasi (Ghana) through data based on responses to a structured questionnaire from 210 SMEs in Kumasi. We report that majority of SMEs fail to maintain complete accounting records as they think there is no need to keep accounting records and that it exposes their financial position. It is recommended that training programmes must be organised to sensitize owners/managers on the need to maintain proper books of accounts. The government should also come out with the necessary legal instruments to make the preparation of proper books of accounts mandatory in order to improve SMEs practice of accounting in Ghana.
\end{abstract}

Keywords: record keeping, accounting practices, financial management, SMEs, Ghana

\section{Introduction}

The contribution of Small and Micro Enterprises (SMEs) to the economic development of most developing countries is overwhelming. Providing employment for almost two-thirds of the countries working population, contributing to the government revenue generation through the payment of income tax, as well as providing income in terms of profits, dividends and wages to households just to mention a few, has been the ultimate hallmark of SMEs to a developing country of which Ghana is no exception. As Prasad et al. (2001) contend, growing SMEs will also contribute to expanding the size of the directly productive sector in the economy; generating tax revenue for the government; and, all in all, facilitating poverty reduction through fiscal transfers and income from employment and firm ownership.

Comparatively, most SMEs are not registered as corporate bodies but as sole proprietorship this makes registration procedures quite simple and a bit easier than the other forms of business registration. Partly due to this phenomenon, SMEs has outnumbered all the other forms of business and could be found almost everywhere across the country. In spite of their numbers, and significance, recent studies show that $60 \%$ of the SMEs fail within the first five years of operation (Boachie et al., 2005). Studies also show that it is hard for the SMEs to access finances from the financial institutions since they lack proper financial records as a requirement (William, 2008). The SMEs inability, many times to live beyond their first few months of existence has been attributed partly to lack of finance. To become successful and be able to contribute meaningfully to the Ghanaian economy, SMEs must attract and secure finance all by themselves.

Providers of finance more often than not, rely on information before making the final decision to either invest or not to invest in a given business. Banks for example, will need to know whether the SME seeking finance will be able to pay the principal amount as well as the interest before going ahead to grant the facility. This is particularly true of financial accounting information about a firm's operations. An adequate accounting system will generate the needed financial accounting information for whatever purpose. It is recommended that SMEs keep detailed accounting records and audit their financial statements on an annual basis. This will enable the banks to make a proper evaluation of SMEs, which should improve their accessibility to credit (Olufunso et al., 2010). Unfortunately because most SMEs in Ghana are managed by owner, they sometimes believe they have less need for financial accounting information because of their personal involvement in the day-to-day operations. This assertion may not be entirely true especially when it has to do with looking for finance. 
To enable seekers of finance and providers of finance makes an informed economic decision; there is the need to have reliable accounting information which has been generated through an adequate accounting system. That requires that proper books of account are kept. An inadequate accounting system is a primary factor in small business failures. Quality of SME records keeping attract investors to invest and for financial institution to provide finance (Tagoe et al., 2001).

For most developing countries including Ghana, achieving low unemployment, improving income levels and reducing poverty which eventually lead to economic success largely depends on whether our SMEs are doing well or not. For the SMEs also to do well there is the need for them to attract and secure finance. Providers of finance will not invest or provide funds unless they are assured that they will not lose their investment. Most providers of finance assure themselves with financial accounting information generated from an adequate accounting system in order to reduce risk.

The question now is, do the SMEs have in place proper books of accounts to generate the much needed accounting information that providers of finance and other business partners require? The answer to the above question makes it imperative for the researcher to look at financial accounting practices of SMEs in Ghana.

The study is relevant in the Ghanaian context given the important role SMEs play in the economic development. There is the need to explore the accounting practices of SMEs in Ghana and to ascertain whether they are able to meet the expectations of finance providers. This will improve SMEs access to funds and improve the performance of the general level of economic activity. The study will add to the literature on accounting practices of SMEs and therefore add to a body of knowledge. The study will also have important policy implications for the government of Ghana and SMEs in general.

The remainder of the paper will be organized as follows: Section two provides a review of the extant literature in the area. Section three discusses the empirical methodology and results. The last section concludes the discussion and provides some policy recommendations based on the findings of the study.

\section{Review of Existing Literature}

\subsection{Accounting Practices of SMEs}

A review of the existing body of research reveals that the importance of keeping proper accounting records, the reasons for keeping accounting records, the extent of record keeping and the nature of accounting systems maintained by SMEs is documented, though limited. Due to the qualitative nature of such studies, questionnaire and interview methodology have been employed by most of the studies.

A strand of the literature looks at the importance of accounting systems on the basis of its application in assessing the performance of businesses by all stakeholders (see, for example, Page, 1984). Olson et al. (2004) argues that accounting information users in SMEs is on the increase. Another aspect of the studies claim that, in the process of planning for profit, financial information is assembled in a way that can help make informed judgment and take decisions concerning the organisation (Copeland \& Dascher, 1978). An accounting system is one of the most effective decision making tools of management. It provides an orderly method of gathering and organising information about the various business transactions so that it may be used as an aid to management in operating the business.

An emphasis is laid on the significance of keeping proper books of accounts by Biryabarema (1998) because it enables small businesses to have accurate information on which to base decisions. SMEs project purchase and sales, determine break-even point, and make a wide range of other financial analyses based on accounting information. The study contends that, lack of proper accounting records has seen the closure of some businesses, and thus makes it a significant issue for business success.

Other studies assert that the high incidence of failure among SMEs could be attributed to the poor accounting systems used by these enterprises (see, for example, Ofonagoro, 1983). Those studies recount that since accounting systems play a key role in determining business growth and profitability, there is a need to evaluate the accounting systems used by SMEs. This is important because for optimum business growth, SMEs must make use of a system of accounting which will enable them determine the volume of sales, profits (or loss), assets and liabilities at any given time.

According to Lybaert (1998), the quality of accounting information utilized within the SME has a positive relationship with an entity's performance and survival. Similarly, it has been emphasized that there is the need for financial information for small and micro business units due to the volatility normally associated with their situation such as unstable cash and profit positions, and reliance on short-term borrowing (McMahon \& Holmes, 1991; Dodge, Fullerton \& Robbins, 1994). 
Kinney (2001) posits that accounting is one of the important types of information for decision making both within and outside the organization. He further states that the quality of this information gauged by its relevance and its reliability for a particular decision is equally important.

In the words of Osuala (1993), many enterprises record their transactions randomly without adherence to any established systems of accounting; hence making it difficult in keeping track of the cash flows in the enterprises. Mitchel et al. (2000) argued that accounting information could help SMEs manage short-term problems in such areas as costing, expenditure and cash flow by providing information to support monitoring and control.

Knowledge of cash-flows according to Pandy (1991) is very important because cash-flows are inseparable parts of the business operations of firms. Peren and Grant (2000) noted that decision making processes in small scale enterprises are more sophisticated than anticipated but they lacked effective accounting information and control system to support their decisions. Furthermore, there is some evidence to suggest that small firms are aware of the importance of accounting information (International Federation of Accountants, 2006). In spite of this awareness, most owners of small entities in Ghana are not too keen to use standard accounting systems to run the day-to-day activities of their enterprises. The high rate of failure of small scale enterprises in developing countries like Ghana, has generally been traced to poor management and accounting systems employed by these enterprises (Ofonagoro, 1983).

There seems to be some consensus on the significance of financial accounting systems to business success. Some researchers assert that the quality of financial accounting information employed within the SMEs sector has a positive relationship with the performance of the entity (see, Lybaert, 1998; Nayak \& Greenfield, 1994; Holmes \& Nicholls, 1989; Raymond \& Magnenat-Thalman, 1982).

In spite of the considerable amount of studies conducted in accounting over the last few decades, there has been little effort on investigating the accounting systems maintained by SMEs and their effectiveness (McChlery et al., 2005). For instance, Mitchell, Reid and Smith (1999) and Marriott and Marriot (2002) observed that, in the United Kingdom only recently had research been directed towards the financial management systems that operate within small-sized enterprises.

To date, limited research has been carried out into the accounting systems in use within small firms. Financial management systems have been analysed for micro businesses of less than 10 employees (Nayak \& Greenfield, 1994), of less than 20 employees (Holmes \& Nicholls, 1989), whilst Mitchell et al. (1999) focused their attentions on new small businesses. On their part, Perren and Grant (2000) considered how management accounting routines developed within small businesses focusing on growth-orientated organisations. Peel and Wilson's (1996) study of firms employing 50 employees or less, was restricted to only 82 respondents. Obviously, there is a need to research the small businesses community across a spectrum of sectors including newly formed and established firms (McChlery et al., 2005).

Poor record keeping is also cited as a cause for start-up business failure. In most cases, this is not only due to the low priority attached to it, but also a lack of the basic business management and skills. Most business operators, therefore, end up losing track of their daily transactions and find it difficult to account for their expenses and their profits at the end of operations. According to Wichman (1983), accounting is a major challenge to management of SMEs. The study recommends that SME managers and/or owners need to learn about proper accounting or engage the services of accounting experts for accounting reporting purposes.

Some authors believe that accounting reports play a significant role in SMEs. However, they argue that such accounting reports must be customised to suit the needs of SMEs. There have been proposals that the use of the cash basis must be preferred the accruals basis of accounting. A study by McMahon (1999) finds that financial reporting practices in SMEs appear to fall short of the standards recommended by various external financial information users imperatives that exist for them, and further claim that SME managers/owners appear mostly reluctant to produce financial reports which might become accessible to outside parties either through the regulatory authorities or directly.

\subsection{Reasons for Keeping Financial Records}

Some aspects of the existing research delve into the relationship between record keeping and performance of firms. Tanwongsval and Pinvanichkul (2008) comment on the reasons why SMEs prepare financial statements, and argue that on the list, SMEs rank assessing profitability second to the purpose of tax returns. According to Cooley and Edwards (1983), owners of SMEs consider profit maximization as the most important financial objective. This has led to the argument that SME owners pay attention to profitability and measurement of net profit when are evaluate their firms performance (see, Page, 1984). 
Holmes and Nicholls (1998) concludes that the extent of accounting practices in SMEs depend on a number of factors such as age of business, size of the business, and the nature of the industry. They further point out that most SME owners and managers engage public accountants to prepare required information. According to Ismail and King (2007), the development of a sound accounting system in SMEs hinge on owners level of accounting knowledge and skills. Some authors have argued that small businesses use professional accounting firms for preparation of annual reports and for other accounting needs (see, Keasy \& Short, 1990; Bohman \& Boter, 1984). Lalin and Sabir (2010), reports that the main drivers why SMEs prepare financial statements is pressure from regulatory authorities.

Hussein (1983) notes that, a good accounting system is not only judged by how well records are kept but by how well it is able to meet the information needs of both internal and external decision-makers. Clute and Gitman (1980) uphold that it is common for qualified accountants to do a good job of keeping records up to date but they fail to provide information needed by decision-makers. Interestingly, however, others argue that the high cost of contracting professional accountants has left SME owners with no better option but to relegate management of accounting information (see, for example, Evaraert et al., 2006; Jayabalan \& Dorasamy, 2009). Zhou (2010) has proposed the use of accounting software to improve accounting practices, albeit he laments the unavailability of medium-sized software for SMEs.

A study conducted in Zimbabwe on 100 SMEs by Maseko and Manyani (2011) brings out that SMEs do not keep complete records of accounts due to lack of knowledge in accounting and the cost of engaging professional accountants. Consequently, the use of accounting information to support measurement of financial performance by SMEs is ineffective. The study proposes that regulatory bodies must develop specific guidelines for SME accounting and organise accounting training programmes for entrepreneurs in small businesses. They also recommend the application of mandatory record keeping to improve accounting practices of SMEs in Zimbabwe.

Mbroh and Attom (2011) studies 217 out of 250 SMEs in Ghana and reports that 59\% do not practice formal accounting at all. The reasons they gave to this include low levels of education and inadequate knowledge in accounting which makes it difficult for them to appreciate the need to practice accounting in their business.

In a study of 148 respondents in Nigeria (Enugu), Okoli (2011) links proper record keeping and profitability of small scale enterprises and assert that due to inadequate record keeping, the small scale operators could not assess their performances effectively. He argues that in order to enhance the profitability of small scale enterprises and their continuity, there is need for adequate record keeping which will help the proprietors to keep track of the performance of these enterprises.

Mensah et al. (2007) states that a significant number of enterprises in their survey kept no records pertaining to operations, finance, audited accounts, tax returns, and so on. Until recently, all the micro and small enterprise could not receive credit from the banks and promotional institutions on grounds that the formal banking sector considered them a high risk area, and hence charged them high cost for borrowed funds from the banks.

In assessing the financial statements of micro and small enterprises, Aryeetey et al. (1994) claims the existence of practical problems in deriving records and figures that make up the statements. One reason for that is because for almost all enterprises the owners keep all the records in memory and hence the lack of records of all kinds sales, marketing, accounting, credit borrowing from lending institutions, staff costs, owners emoluments, etc. Owners of SMEs do not keep proper records and thus, they are not able to provide data about their entities.

\section{Methods and Results}

\subsection{Data Collection}

The study applies descriptive quantitative survey method. This method entails gathering of data from primary sources aimed at achieving the objectives of the research. The sampled population comprised of 260 SMEs in the Kumasi Metropolitan Assembly of Ghana. We based on the objectives to develop the questionnaire for the survey and possible responses. Data for the study was gathered from Managers and/or Owners of SMEs through self designed questionnaire covering the various variables identified in the literature. A literature review was conducted on both primary and secondary resources. This covered all the key concepts that were used in the study to provide the theoretical framework and background against which an important tool of the study, the questionnaire was developed. The review in addition, provides the basis for discussions and support for many views that were presented in the study and also added some weight to the conclusions drawn, and recommendations made. 
The questionnaire had three major sections. The first part covered the demographic profile of the respondents followed by the profile of the business entity. The next section covered the question that sought to categorise respondents into whether proper books of accounts is maintained or not. Finally, after the categorisation, respondents were asked to give reasons why they maintain or do not maintain accounting records.

The non-probability convenience sampling technique was employed to distribute the questionnaires to 260 Managers/Owners of SMEs. With the support of friends and colleagues the questionnaires were sent to retail shops (including Owners/Managers of provisions, pharmaceuticals, hardware, building materials), general merchants, manufacturing entities (including metal and glass fabricators, furniture works, printing and stationeries) and a range of other service providers (including guest or rest houses, restaurants, private schools), etc.

In all about 260 questionnaires were sent out to collect the necessary data for the study. About 224 of the questionnaires were returned, which gives a return rate of $86.15 \%$. Out of the 224 questionnaires, there were 14 which were not properly completed and therefore could not be used as part of the analysis. The number of questionnaire used for the analysis for the study was 210 . We adopted descriptive techniques and measures of central tendency to analyze the responses. Besides, some results are presented using tables.

\subsection{Empirical Results}

\subsubsection{Profile of Respondents and Surveyed Firms}

\section{i. Age and Gender}

Out of 210 respondents survey, 125 (59.52\%) were males, while 85 (40.48\%) were females (refer to Table 1 below). We reports further that, of the 210 respondents, $41(19.52 \%)$ were $20-30$ years, $84(40.00 \%)$ were $31-40$ years, while $58(27.62 \%)$ were $41-50$ years. Also, there were $22(10.48 \%)$ who were between the ages of $51-60$ years.

Table 1. General characteristics of respondents

\begin{tabular}{lll}
\hline Gender & Frequency & Percentage \\
\hline Male & 125 & $59.52 \%$ \\
Female & 85 & $40.48 \%$ \\
Total & 210 & $100.00 \%$ \\
Age (years) & Frequency & Percentage \\
$20-30$ & 41 & $19.52 \%$ \\
$31-40$ & 84 & $40.00 \%$ \\
$41-50$ & 58 & $27.62 \%$ \\
$51-60$ & 22 & $10.48 \%$ \\
$60+$ & 5 & $2.38 \%$ \\
Total & 210 & $100.00 \%$ \\
Qualification & Frequency & Percentage \\
GCE/SSCE or below & 117 & $55.71 \%$ \\
Post-Sec & 45 & $21.43 \%$ \\
Diploma & 17 & $8.10 \%$ \\
Degree & 12 & $5.71 \%$ \\
Others & 19 & $9.05 \%$ \\
Total & 210 & $100.00 \%$ \\
Level of Accounting Skills & Frequency & Percentage \\
Low skills & 103 & $49.05 \%$ \\
Below Average & 52 & $24.76 \%$ \\
Average & 31 & $14.76 \%$ \\
Above Average & 17 & $8.10 \%$ \\
High skills & 7 & $3.33 \%$ \\
Total & 210 & $100.00 \%$ \\
\hline
\end{tabular}




\section{ii. Educational Qualification}

One critical element used in understanding the behaviour of business owners and managers is their educational qualification. To a larger extent, most Ghanaians are of the view that, to be successful in understanding the dynamics and challenges posed by business management one needs a reasonable higher educational background. The level of educational attainment influences the understanding of the importance of maintaining proper books of accounts. Also, it is expected that if a business owner has a reasonable level of education it will indisputably affect his influence on implementing the necessary accounting and control systems in the business. Our results indicate that more than $72 \%$ of the respondents had qualifications below Diploma. Over $55 \%$ of the respondents have below or up to second-cycle qualification.

\section{iii. Level of Accounting Skills}

Since the literature points out level of accounting skills as one of the reasons why most SMEs do not have interest in preparation of accounting records, we sought to understand respondents own rating of their level of accounting skills. It turned out that, close to $50 \%$ rated their level of accounting skills as below average. A little over $10 \%$ of respondents ranked their level as average or above average.

\section{iv. Profile of Firms}

Our questionnaire captured the profile of firms surveyed in terms of nature of business, ownership structure, number of employees, as shown in Table 2. Most of the businesses in the survey were either managed by the owner or a close relative and a larger percentage employed less than 5 staff. On the ownership structure of business, close to $90 \%$ of the firms surveyed were classified as sole proprietorship. Most of these businesses were managed by their owners. Also, the nature of the business indicated that majority of the businesses surveyed were involved in retailing. This segment comprises of dealers in provisions, fashion and clothing, general merchandise, etc and makes up over $60 \%$ of the surveyed firms. Services follows with a little over $24 \%$ whereas the wholesale segment follows with $10 \%$ and less than $6 \%$ for manufacturing.

Table 2. General profile of firms

\begin{tabular}{ccc}
\hline Ownership & Frequency & Percentage \\
\hline Sole Proprietor & 188 & $89.52 \%$ \\
Partnership & 3 & $1.43 \%$ \\
Family & 8 & $3.81 \%$ \\
Limited Liability & 11 & $5.24 \%$ \\
Total & 210 & $100.00 \%$ \\
Nature of business & Frequency & Percentage \\
Retail & 127 & $60.48 \%$ \\
Wholesale & 14 & $6.67 \%$ \\
Services & 51 & $24.29 \%$ \\
Manufacturing & 18 & $8.57 \%$ \\
Total & 210 & $100.00 \%$ \\
\hline
\end{tabular}

\subsubsection{Keeping Accounting Records}

After taking some general information from the respondents and the firm, the main questioned was posed: "Do you keep accounting records?" This question sought to categorise the respondents. Those who respond "yes" will continue to answer questions on accounting records whilst those who answered "no" were asked to give reasons why accounting records are not kept to get to the end of the road.

Out of the 210, 35.24\% respondents answered yes. The "yes" meant that, per their own understanding of accounting records they are in place. The records are of two forms: the books of account and financial report. The books are the Receivables ledger, Payables ledger, Cash book, General ledger, etc whereas the statements came in the form of Statement of Financial Position, Income Statement (popularly known to them as Profit and Loss Account), Cash Flow Statement, and others. The respondents have different forms of records and their understanding of accounting record is subject to further justification. The 136 who answered "No" are those whose records, even when they have, do not follow any prescribed manner to make it qualify for a classification under any accounting record. 
Table 3. Response on whether the firm maintains accounting records or not $(\mathrm{N}=210)$

\begin{tabular}{ccc}
\hline Records & Frequency & Percentage \\
\hline Yes & 74 & $35.24 \%$ \\
No & 136 & $64.76 \%$ \\
Total & 210 & $100.00 \%$ \\
\hline
\end{tabular}

Those who answered "No" $(\mathrm{N}=136)$ were asked whether they kept any form of records for their transactions. Of the 136 respondents, $109(80.15 \%)$ answered that they kept some "informal" notes that guide them to track their debtors but such notes do not follow any order to make it qualify for any form of accounting records. This implies that less than $20 \%$ of those who do not maintain accounting records have no records at all for their transactions. Table 4 has this report. According to those who keep some personal notes of transactions, the strategy is meant to curtail any form of challenges to be posed in the absence of formal accounting. Although this situation may be convenient and serve as a useful internal guide to some owners, it trounces the purpose of accounting. This is because it becomes very difficult to present the business to the outside world to ensure confidence in the business and ultimately inhibit the growth of the business.

Table 4. Response on whether the firm maintains any form of records $(\mathrm{N}=136)$

\begin{tabular}{ccc}
\hline Records & Frequency & Percentage \\
\hline Yes & 109 & $80.15 \%$ \\
No & 27 & $19.85 \%$ \\
Total & 136 & $100.00 \%$ \\
\hline
\end{tabular}

\subsubsection{Motivation/Purpose for Maintaining Accounting Records}

After establishing that there are close to $65 \%$ of the respondents who do not keep accounting records, we sought to determine what motivates others to maintain accounting records. The strengths of factors that serve as motivation were measured using a five-point Likert scale and mean score and standard deviation were computed for each item. Respondents were asked to rate 6 reasons for deciding to prepare and maintain accounting records using the five-point Likert scale with five being "strongly agree" and one being "strongly disagree." A higher mean score for a factor indicates greater importance. Table 5 shows that respondents agree that the main purpose for keeping the records is "to keep track of receivables and payables". A larger percentage of respondents agree that it is important to monitor what is $\mathrm{A} / \mathrm{R}$ and $\mathrm{A} / \mathrm{P}$ when running a business. $\mathrm{A} / \mathrm{R}$ is important because you need to know (and have records on) how many of your customers owe you money; $\mathrm{A} / \mathrm{P}$ is important because you need to know how much you owe. The mean and standard deviation for this factor are 3.93 and 1.16 respectively. The other factors that rank high are "performance evaluation purposes" and "to assist in accessing credit/finance" with mean scores 3.42 and 3.34 respectively. The lowest ranked factor among those presented was "for income distribution purposes" at 2.88. This observation holds very well since in Ghana partnership businesses are not many.

Table 5. Motivation/purpose for maintaining accounting records $(\mathrm{N}=74)$

\begin{tabular}{lccc}
\hline & Mean & Standard Deviation & Rank \\
\hline Taxation purpose & 3.28 & 1.24 & $4^{\text {th }}$ \\
Income distribution purpose & 2.88 & 1.36 & $6^{\text {th }}$ \\
Performance evaluation purpose & 3.42 & 1.32 & $2^{\text {nd }}$ \\
Tracking of receivables and payables & 3.93 & 1.16 & $1^{\text {st }}$ \\
For support in accessing credit/finance & 3.34 & 1.46 & $3^{\text {rd }}$ \\
To determine the size of business & 3.26 & 1.44 & $5^{\text {th }}$ \\
\hline
\end{tabular}




\subsubsection{Why Accounting Records Are not Kept}

After the respondents have been categorised into two, those who do not keep accounting records were asked to rank a list of eight possible reasons to justify why they do not do that. The five-point Likert scale used to measure the extent of agreement or otherwise had 5 as "strongly agree", 4 as "agree", 3 as "uncertain", 2 as "disagree" and 1 as "strongly disagree". A higher mean score on a variable indicates a strong agreement. We present the results in Table 6. Respondents agreed that the main reason for it is that "There is no need to keep accounting records". It has a mean of 4.05 and standard deviation of 1.08. This means that the respondents do not see the need to keep accounting records. Again, this was followed by reasons like "It exposes your financial position" and "It makes your enterprise pay more tax" with mean of 4.00 and 3.82 respectively.

Table 6. Reasons why SMEs do not keep accounting records $(\mathrm{N}=136)$

\begin{tabular}{lccc}
\hline & Mean & Standard Deviation & Rank \\
\hline It is time consuming & 3.81 & 1.12 & $4^{\text {th }}$ \\
It is expensive & 3.74 & 1.10 & $5^{\text {th }}$ \\
It requires technical skills \& knowledge & 3.70 & 1.24 & $6^{\text {th }}$ \\
It requires more staff & 3.65 & 1.18 & $8^{\text {th }}$ \\
It exposes your financial position & 4.00 & 1.04 & $2^{\text {nd }}$ \\
It makes your enterprise to pay more tax & 3.82 & 1.04 & $3^{\text {rd }}$ \\
There is no need to keep accounting records & 4.05 & 1.08 & $1^{\text {st }}$ \\
It is difficult to maintain the system & 3.69 & 1.15 & $7^{\text {th }}$ \\
\hline
\end{tabular}

\subsubsection{Challenges of Using and Keeping Accounting Records $(\mathrm{N}=74)$}

We used a five-point Likert scale, with four as "strongly agree" and one as "strongly disagree", respondents rated 7 possible challenges to be faced in maintaining accounting records in terms of its preparation and the problems they present for the business. Results presented in Table 7 indicate that the reason that "It requires technical knowledge" was rated as the most important challenge at 4.16, followed by "It is expensive" at 3.70. In the list of challenges presented, those rated as least problematic are "It makes your enterprise pay more tax", "It exposes your financial position" followed by "It requires more staff". This implies that respondents are in agreement that since it is technical it makes it very expensive. Although it presents challenges related to paying more taxes or exposing your financial position, once they have decided to keep the records it is not an important challenge for them.

Table 7. Challenges of using and keeping accounting records $(\mathrm{N}=74)$

\begin{tabular}{lccc}
\hline & Mean & Standard Deviation & Rank \\
\hline It is time consuming & 3.62 & 1.12 & $3^{\text {rd }}$ \\
It is expensive & 3.70 & 1.18 & $2^{\text {nd }}$ \\
It requires technical knowledge & 4.16 & 0.99 & $1^{\text {st }}$ \\
It exposes your financial position & 3.24 & 1.24 & $6^{\text {th }}$ \\
It requires more staff & 3.41 & 1.24 & $5^{\text {th }}$ \\
It makes your enterprise pay more tax & 3.16 & 1.34 & $7^{\text {th }}$ \\
It is difficult to maintain the system & 3.49 & 1.16 & $4^{\text {th }}$ \\
\hline
\end{tabular}

\subsubsection{Suggestions on How to Improve the Accounting Practices of SMEs}

On their opinion of what could be done to improve the accounting practices of SMEs, a list of eight suggestions was presented for respondents to rank. Similar to previous techniques, a five-point Likert scale with 5 being "strongly agree" and 1 as "strongly disagree" was applied. The result is presented in Table 8 and we can see that respondents agree that educating managers and owners on the need to keep accounting records is paramount. This is in agreement with the fact that most of the respondent who do not keep the records are of the opinion that it is of no use to keep them. 
Table 8. SMEs opinion of how to improve their accounting practices

\begin{tabular}{lccr}
\hline & Mean & Standard Deviation & Rank \\
\hline Organise training for managers and owners & 3.94 & 0.91 & $2^{\text {nd }}$ \\
Hire consultants for SMEs for financial statement analysis & 3.17 & 1.09 & $6^{\text {th }}$ \\
Make the use of accounting records mandatory & 2.86 & 1.38 & $7^{\text {th }}$ \\
Offer free accountancy services & 3.61 & 1.12 & $4^{\text {th }}$ \\
Motivate managers/owners to adopt accounting records & 3.83 & 0.99 & $3^{\text {rd }}$ \\
Strengthen monitoring and supervision & 3.18 & 1.16 & $5^{\text {th }}$ \\
Educate managers/owners on the need to keep accounting records & 4.16 & 0.92 & $1^{\text {st }}$ \\
\hline
\end{tabular}

\section{Conclusion and Policy Recommendations}

The study seeks to explore the accounting practices of SMEs in Ghana. The results reveal that SMEs do not maintain proper books of accounts because owners do not appreciate the need to keep accounting records, lack the necessary accounting knowledge and blame the cost of hiring accounting professional. Consequently, the application of accounting information to support assessment of financial performance by SMEs in Ghana is inefficient.

Accounting training programmes for SMEs should be initiated by the Ministry responsible for Trade and Industry for those who do not know about the importance of maintaining accounting records to come to grips with it. This strategy will help them to advance their accounting practices and bring about the possibility of formalizing their operations. As critical as accounting information is in managing relationships with the outside world, owners and managers need to understand the role of such information in the form of clear financial statements in ensuring proper justification for business transactions and state of affairs.

We recommend that, as a means of motivation, the authorities should design specific guidelines for SMEs accounting and provide templates for accounting practices of SMEs. This strategy will reduce the technicalities involved in maintaining accounting records and also make the whole process very simple and friendlier.

Since most of the respondents seem not to support attempts of making it mandatory to maintain proper accounting records and subsequently produce final accounts, we recommend that accounting record in SMEs become mandatory. We maintain that proper accounting is paramount in any business and that it is crucial in tracking all aspects of the business from the information contained in the books - as in what is happening in the business, how much has been sold, what the costs are, what activities are profitable, whether selling prices leave a suitable margin against cost and so on.

The government should put in place a regulatory body to ensure that SMEs keep proper books and prepare final accounts. This will not only ensure the proper declaration of income and increase tax revenue to the government but also make available proper data for national income accounting which usually influences major government policies. To the extent that such information is required by business owners and government, the necessary legal instruments and proper monitoring must be in place to ensure compliance.

\section{References}

Aryeetey, E., Baah-Nuakoh, A., Duggleby, T., Hettige, H., \& Steel, W. F. (1994). Supply and Demand for Finance of Small-Scale Enterprises in Ghana. World Bank Discussion Paper No. 251. Washington, D.C.: The World Bank. http://dx.doi.org/10.1596/0-8213-2964-2

Biryabarema, E. (1998). Small Scale Business and Commercial Banks in Uganda. Kampala: Makerere University Press.

Boachie-Mensah, F. O., \& Marfo-Yiadom, E. (2005). Entrepreneurship and Small Business Management. Accra: Ghana Universities Press.

Bohman, H., \& Boter, H. (1984). Planning in small and medium-sized firms-The challenges and premises of the strategic planning. Department of Business Administration and Economics, Umea University Sweden.

Clute, R. C., \& Gitman, G. B. (1980). A Factor Analytic Study of the Causes of Small Business Failure. Journal of Small Business Management, 30(2).

Cooley, P. L., \& Edwards, C. E. (1983). Financial objectives of small firms. American Journal of Small 
Business, 8(1), 27-31.

Copeland, R. M., \& Dascher, P. E. (1978). Managerial Accounting. New York, NY: John Wiley.

Dodge, H., Fullerton, S., \& Robbins, J. (1994). Stage of the organizational life cycle and competition as mediators of problem perception for small businesses. Strategic Management Journal, 15, 121-134. http://dx.doi.org/10.1002/smj.4250150204

Everaert, P., Sarens, G., \& Rommel, J. (2006). Outsourcing of Accounting Tasks in SMEs: An extended TCE Model. Working Paper No. 2004/403. Universiteit Gent. Kuiperskaai, Belgium.

Holmes, S., \& Nicholls, D. (1988). An Analysis of the Use of Accounting Information by Australian Small Business. Journal of Small Business Management, 26(2), 57-68.

Holmes, S., \& Nicholls, D. (1989). Modeling the accounting information requirements of small businesses. Accounting and Business Research, 19(74), 143-150. http://dx.doi.org/10.1080/00014788.1989.9728844

Hussein, M. E. I. M. (1983). Accounting and Control Systems for Small Business. Touché Ross Foundation.

International Federation of Accountants. (2006). Micro-Entity Financial Reporting: Perspectives of Preparers and Users, Small and Medium Practices Committee. New York, NY: International Federation of Accountants.

Ismail, N. A., \& King, M. (2007). Factors influencing the alignment of accounting information in small and medium sized Malaysian firms. Journal of Information System and Small Business, 1(1-2), 1-20.

Jayabalan, J., \& Dorasamy, M. (2009). Outsourcing of Accounting Functions amongst SME companies in Malaysia: An Exploratory Study. Accountancy Business and the Public Interest, 8(2), 96-114.

Keasy, K., \& Short, H. (1990). The accounting burdens facing small firms: An empirical research note. Journal of Accounting Business Research, 20(80), 307-313. http://dx.doi.org/10.1080/00014788.1990.9728889

Kinney, W. R. (2001). Accounting scholarship: What is uniquely ours? The Accounting Review, 76(2), 275-284. http://dx.doi.org/10.2308/accr.2001.76.2.275

Lalin, H., \& Sabir, R. I. (2010). Research on Usage and Usefulness Perception of Financial Accounting Practices in Less Developing Countries: A case of Cambodia. Proceedings of the Proceedings of the 7th International Conference on Innovation \& Management, 1881-1885.

Lybaert, N. (1998). The Information use in an SME: Its Importance and some Elements of Influence. Small Business Economics, 10(2), 171-191. http://dx.doi.org/10.1023/A:1007967721235

Marriot, N., \& Marriott, P. (2000). Professional Accountants and the Development of a Management Accounting Service for the Small Firm: Barriers and Possibilities. Management Accounting Research, 11, 475-492. http://dx.doi.org/10.1006/mare.2000.0142

Maseko, N., \& Manyani, O. (2011). Accounting practices of SMEs in Zimbabwe. Journal of Accounting and Taxation, 3(8), 171-181.

Mbroh, J. K., \& Attom, E. B. (2011). Accounting and Control Systems Practiced By Small and Micro Enterprise Owners within the Cape Coast Metropolitan Area of Ghana. Asian Journal of Business and Management Sciences, 1(9), 28-47.

McChlery, S., Godfrey, A. D., \& Meechan, L. (2005). Barriers and Catalysts to sound Financial management Systems in Small-Sized Enterprises. The Journal of Applied Accounting Research, 7(3), 1-26. http://dx.doi.org/10.1108/96754260580001040

McMahon, R. G. P. (1999). Putting SME Financial Reporting into Theoretical and Practical Perspective. Research Paper Series 98-10. The Flinder University of South Australia, Adelaide.

McMahon, R. G. P., \& Holmes, S. (1991). Small Business Financial Management Practices in North America: A Literature Review. Journal of Small Business Management, 19-29.

Mensah, J. V., Tribe, M., \& Weiss, J. (2007). The small-scale manufacturing sector in Ghana: A source of dynamism or of subsistence income? Journal of International Development, 19(2), 253-273. http://dx.doi.org/10.1002/jid.1322

Mitchell, F., Reid, G., \& Smith, J. (1998). A Case for Researching Management Accounting in SME's. Management Accounting: Magazine for Chartered Management Accountants, 76, 30-33.

Mitchell, F., Reid, G., \& Smith, J. (2000). Information system development in the small firm: The use of 
management accounting. London: CIMA Publishing.

Nayak, A., \& Greenfield, S. (1994). The use of Management Accounting Information for Micro Business. In Hughes, A., \& Storey, D. (Eds.), Finance and the Small Firm. London: Routledge.

Ofonagoro, A. O. (1983). September 30 Need for Financial Statement in Small Business. Business Times, 22.

Okoli, B. E. (2011). Evaluation of the Accounting Systems Used by Small Scale Enterprises in Nigeria: The Case of Enugu- South East Nigeria. Asian Journal of Business Management, 3(4), 235-240.

Olson, O., Blomskvisk, M., Dergard, J., \& Jonsson, C. (2004). Accounting and Entrepreneurship: A Review and Discussion of the Scientific Literature. Paper Presented at the 4th Asia-Pacific Interdisciplinary Research in Accounting Conference. 4-6, Singapore.

Olufunso, F. O. (2010). Graduate Entrepreneurial Intentions in South Africa: Motivations and Obstacles. International Journal of Business and Management, 5(9), 87-98.

Osuala, E. C. (1993). Principles and Practices of Small Business Management in Nigeria: A didactic approach. Nsukka: Fulladu Publishing Company.

Pandy, I. M. (1991). Financial Management. New Delhi: Victas Publishing House.

Peel, M. J., \& Wilson, N. (1996). Working Capital and financial Management Practices in the Small Firms Sector. International Small Business Journal, 14(2), 52-68. http://dx.doi.org/10.1177/0266242696142004

Perren, L., \& Grant, P. (2000). The Evolution of Management Routines in Small Businesses: A Social Construction Perspective. Management Accounting Research, 11, 391-411. http://dx.doi.org/10.1006/mare.2000.0141

Prasad, S., Green, C., \& Murinde, V. (2001). Corporate financial structures in developing economies: Evidence from a comparative analysis of Thai and Malay corporations. Working Paper Series, Paper No 35. Finance and Development Research Programme, University of Manchester, Manchester.

Raymond, L., \& Magnenat-Thalmann, N. (1982), Information Systems in Small Business: are they used in Managerial Decisions? American Journal of Small Business, 6, 20-26.

Tagoe, N., Anuwa-Amarh, E., \& Nyarko, E. (2008). SME access to bank finance in an emerging economy: the role of information management practices. International Journal of Financial Services Management, 3(2), 148-170. http://dx.doi.org/10.1504/IJFSM.2008.019668

Tanwongsval, V., \& Pinvanichkul, T. (2008). Accounting Information Requirements and Reporting Practices of Thai SMEs. King Mongkut University Technology, 59-74.

Wichman, H. (1983). Accounting and marketing-key small business problems. American J. Small Bus., 7(4), 19-26.

Williams, J. R., Haka, S. F., Bettner, M. S., \& Carcello, J. V. (2008). Financial and Managerial Accounting. New York, NY: Mc Graw-Hill Irwin.

Zhou, L. (2010). The Research on Issues and Countermeasures of Accounting Information of SMEs. International Journal of Business Management, 5(3), 223-225.

\section{Copyrights}

Copyright for this article is retained by the author(s), with first publication rights granted to the journal.

This is an open-access article distributed under the terms and conditions of the Creative Commons Attribution license (http://creativecommons.org/licenses/by/3.0/). 